\title{
紫外固体レーザー用フッ化物単結晶
}

\author{
島村 清史, Sonia L. Baldochi, Zhenlin Liu* , 猿倉 信彦*, 福田 承生 \\ 東北大学 金属材料研究所 ( T980-8577 宮城県仙台市青葉区片平2-1-1) \\ *岡崎国立共同研究機構 分子科学研究所 ( $4444-8585$ 愛知県岡崎市明大寺町字西郷中 38 )
}

\section{Fluoride Single Crystals for UV Solid-State Laser Applications}

\author{
Kiyoshi SHIMAMURA, Sonia L. BALDOCHI, Zhenlin LIU,* \\ Nobuhiko SARUKURA,* and Tsuguo FUKUDA \\ Institute for Materials Research, Tohoku University, 2-1-1 Katahira, Aoba-ku, Sendai, Miyagi 980-8577 \\ *Institute for Molecular Science, Okazaki National Research Institute \\ 38 Nishigonaka, Myodaiji-cho, Okazaki, Aichi 444-8585
}

(Received May 6, 1999)

\begin{abstract}
A new, highly reproducible crystal growth technique for high quality fluorides has been developed. A series of Ce-doped fluorides free from cracks and inclusions, including $\mathrm{LiCaAlF}_{6}, \mathrm{LiSrAlF}_{6}, \mathrm{LiYF}_{4}$, and $\mathrm{LiLuF}_{4}$, have been grown for UV laser applications. The effective distribution coefficient of $\mathrm{Ce}$ in each crystal has been determined. $60-\mathrm{mJ}$ pulses at $289-\mathrm{nm}$ were generated using $\mathrm{Ce}: \mathrm{LiCaAlF}_{6}$ single crystals. Un-doped $\mathrm{LiCaAlF}_{6}$ single crystal exhibited extended transmission to $112 \mathrm{~nm}$.
\end{abstract}

Key Words: Fluoride, Crystal growth, Colquiriite, Scheelite, UV laser

1.はじめに

全固体紫外波長可変レーザーは高寿命, 高信頼性, 高い 安全性などの優れた特徵をもつことから, 医用, 環境計測 等, 様々な応用分野で開発が期待されている.フッ化物単 結晶材料は高い透過性を有するため, 特に紫外領域での レーザーホスト材料として期待される。ところが,フッ化 物, 特にCe $\mathrm{e}^{3+}$ 添加した高品質フッ化物単結晶の作製, 及び 光散乱体のない単結晶作製は困難であると認識されてき ている。それは一つには,フッ化物の単結晶成長にあたり 原料を危険なガスである乾燥HF中で純化・精製しなけれ ばならない, 或いはHF中で結晶成長を行わねばならない, といった認識があるからである1)。そのため,フッ化物単 結晶はその優れた潜在的特性にもかかわらず,これまで比 較的敬遠され続け, 結果, フッ化物の結晶成長に関する詳 細な報告はほとんどなく,結晶材料の入手自体も非常に困 難な状態が続いている。部入手可能なところがあって も, サイズや品質が十分でない, 或いはロッドにより特性 が大きく異なる,などの問題が発生し続けている。すなわ ち, 紫外波長可変固体レーザーの広い利得領域はナタンサ ファイアレーザーと同様に超短パルス光の増幅・発生へ の応用が期待されているにもかかわらず, 高品位結晶の安 定な供給が難しいため, 偶然にできた数少ない小さな結晶 を頼りに全ての実験を行わねばならないという状況の下，
基礎レーザー特性の評価以外はあまり進んでいないとい うのが現状ではないだろうか.

そこで我々は, 安全, かつ安価な手法により高品質フッ 化物単結晶成長の実現を図り, 今後益々重要となる紫外全 固体レーザー研究を, 優れたフッ化物結晶の提供により加 速的に進展させることができれば, と考えた。こうした単 結晶成長法が実現されれば, 紫外域のみでなく,フッ化物 の特徵を利用できる赤外域での全固体化高効率レーザー の実現, 或いはフッ化物単結晶を必要とするあらゆる分野 にも貢献できる．検討の結果, HFガスを一切使用せず, か つ, 市販品の高純度粉末原料を用い, 引き上げ法により, 再 現性良く, 高品質フッ化物単結晶成長を実現する方法を見 いだし, 高品質フッ化物単結晶成長に成功した。

ここでは, 我々が見いだしたフッ化物の結晶成長法によ る, 紫外固体レーザー材料として期待されるColquiriite型 フッ化物結晶 $\mathrm{LiCaAlF}_{6}(\mathrm{LiCAF}), \mathrm{LiSrAlF}_{6}(\mathrm{LiSAF})$, 及び Scheelite型フッ化物結晶 $\mathrm{LiYF}_{4}(\mathrm{YLF}), \mathrm{LiLuF}_{4}(\mathrm{LLF})$ の結晶 成長, 並びに成長結晶から得られた優れた光学・レーザー 特性について報告する。

\section{Colquiriite型結晶}

Colquiriite型として知られるLiCAF, LiSAFは, 六方晶系に 属する光学的一軸性結晶である。1988年にPayneらにより 
$\mathrm{Cr}^{3+}$ ドープ結晶が開発され, 赤外波長可変レーザー結晶と して研究された2,3)。その後1993年にDubinskiiらにより $\mathrm{Ce}^{3+}$ ドープ結晶が開発され, 紫外レーザー発振に成功した ${ }^{4,5)}$. これらCe:LiCAF, Ce:LiSAFは, Nd:YAGレーザーの第4高調 波 $(266 \mathrm{~nm})$ で励起可能である最初のCeドープ紫外レーザー 媒質である。しかしながら上記に示したように, 高品位結 晶の安定な供給がなく, 紫外レーザー特性は十分な検討が

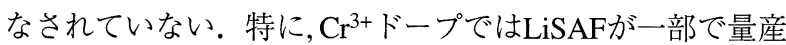

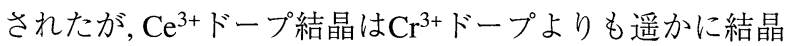
成長が困難とされ,バルクサイズの結晶が得られたという

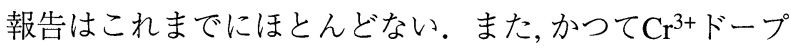
で量産されたLiSAFに比べ, LiCAFはホスト結晶としての 品質が悪く, 得られている特性もLiSAFを下回るもので あった。 そこで我々は, 結晶成長条件の解明, 最適化を試 み,クラック,インクルージョン等のない1インチサイズCe: LiCAF, Ce:LiSAFの結晶成長に成功し, 従来にない大きな 紫外レーザー出力の発生を得た。ここでは,このような潜 在的に優れた特性を有すると期待される Ce:LiCAF, Ce: LiSAFの1インチサイズ単結晶成長, 並びに得られた結晶を 用いての結晶性評価, 光学特性評価について報告する.

\section{1 単結晶成長}

単結晶作製は雲囲気制御型Czochralski装置, 及び白金坩 堝を用いて行った。引き上げ速度, 結晶回転数はそれぞれ $1 \mathrm{~mm} / \mathrm{h}, 15 \mathrm{rpm}$ に固定し, 種結晶には $a$ 軸に配向したCr:LiCAF, $\mathrm{Cr}: \mathrm{LiSAF}$ 用い, $a$ 軸の方位にて引き上げを行った。 原料に は高純度 (99.99\%以上)の $\mathrm{LiF}, \mathrm{CaF}_{2}, \mathrm{SrF}_{2}, \mathrm{AlF}_{3}$ 各フッ化物粉 末を用いた。 添加物には同様の高純度 $\mathrm{CeF}_{3}, \mathrm{NaF}^{2}$ 各フッ化 物粉末を用い, 融液中での濃度をそれぞれ $1 \mathrm{~mol} . \%$ とした。 ここでNaは電荷の中立を保つためCeと同じ比率で添加し

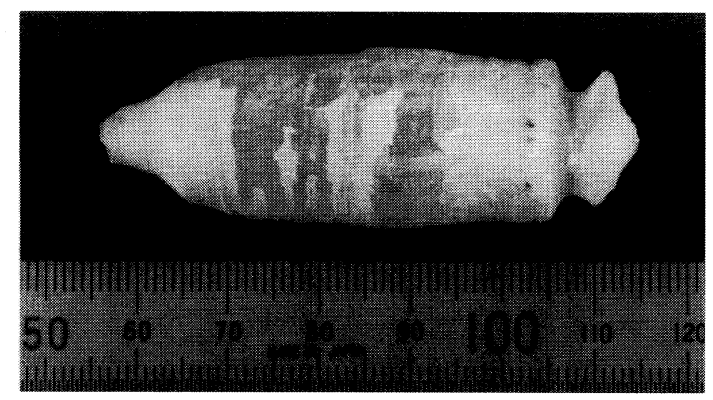

(a)

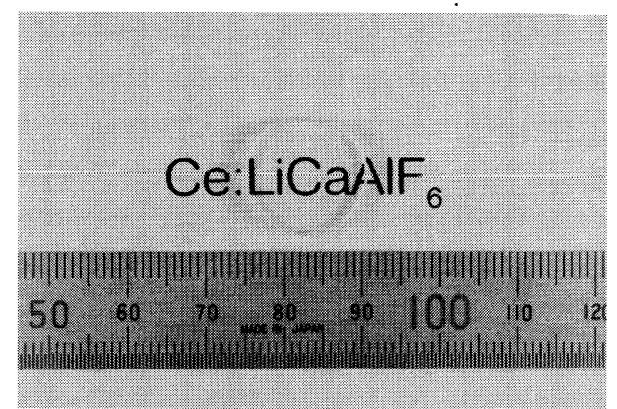

(b)

Fig.1 As-grown Ce-doped $\mathrm{LiCaAlF}_{6}$ single crystal grown under Ar atmosphere (a) and as-grown wafer cut perpendicular to the growth axis (b).
た6). 相の同定には粉末X線回折法 (XRD), 組成分析には EPMA, 赤外域での透過スペクトル測定にはFT-IRを用い た.

まず高純度 $\operatorname{Ar}(6 \mathrm{~N})$ 雲囲気下での結晶成長を試みた。ま た,ガスの置換に先立ち, $10^{-2}$ torrに真空引きを行った。融 液組成は化学量論組成とした。Fig.1（a）に作製したCe: LiCAF結晶を示す. 結晶の表面が多量の白濁物質で覆われ ていた. Ce:LiCAF結晶と同様, Ce:LiSAFにおいても成長結 晶は多量の白濁物質で覆われていた. Fig.1（b)に成長結晶 に対し垂直に切り出し研磨したウェハーを示す．結晶表 面を覆っている白濁物質はごく表面近傍にのみ存在し, 内 部は透明な単結晶であることがわかった。次に高品質化 のため,これら白濁物質について調べてみた. Fig.2に白濁 物質のSEM像を示す. 成長結晶の表面に存在する白濁物 質と, 表面に近い単結晶の中に存在する球状物質の 2 種類が 観察された．表面に存在する物質, および球状物質の双方 をEPMA，XRDにより調べた結果，どちらとも $\mathrm{Al}_{4} \mathrm{LiO}_{6} \mathrm{~F}$, $\mathrm{CaF}_{2}, \mathrm{AlF}_{3}$ と $\mathrm{Li}_{3} \mathrm{AlF}_{6}$ からなる物質であるとわかった。また, 結晶成長中に融液からの多量の蒸発が観察され, チャン バーの内壁などに白濁物質が付着していた。それらも調 べた結果, $\mathrm{AlF}_{3}$ と $\mathrm{Li}_{3} \mathrm{AlF}_{6}$ が混合した物質であることが分 かった.これらの結果より, 白濁物質の発生原因として以 下の二つが考えられる。一つは $\mathrm{AlF}_{3}$ と $\mathrm{Li}_{3} \mathrm{AlF}_{6}$ の蒸気圧が 高く7), 結晶成長中に融液から蒸発し, 結晶表面に付着す る. 融液成分の一部が蒸発するため, 融液組成が変化し, 過 剰となった $\mathrm{CaF}_{2}$ も白濁物質の一部として取り込まれる。 他方, $\mathrm{Al}_{4} \mathrm{LiO}_{6} \mathrm{~F}$ は, 炉内, 原料中に存在する微量の水分が粉 末原料と反応したものと考えられる。

上記白濁物質発生を抑制するため, 以下のような成長条 件の最適化を行った. 蒸発の抑制のための緩やかな温度 勾配の達成, 並びに水分・酸素の発生源となる物質を一切 炉内から排除する目的で, 加熱源を高純度グラファイトを 用いる抵抗加熱型とした．水分除去の効率化を図るため には,ロータリーポンプとディフュージョンポンプの2種類 のポンプを使用し, $10^{-5}$ torr台まで真空度が達成できるよう にした。更に, 結晶成長雲囲気としては, 高純度Arのかわ

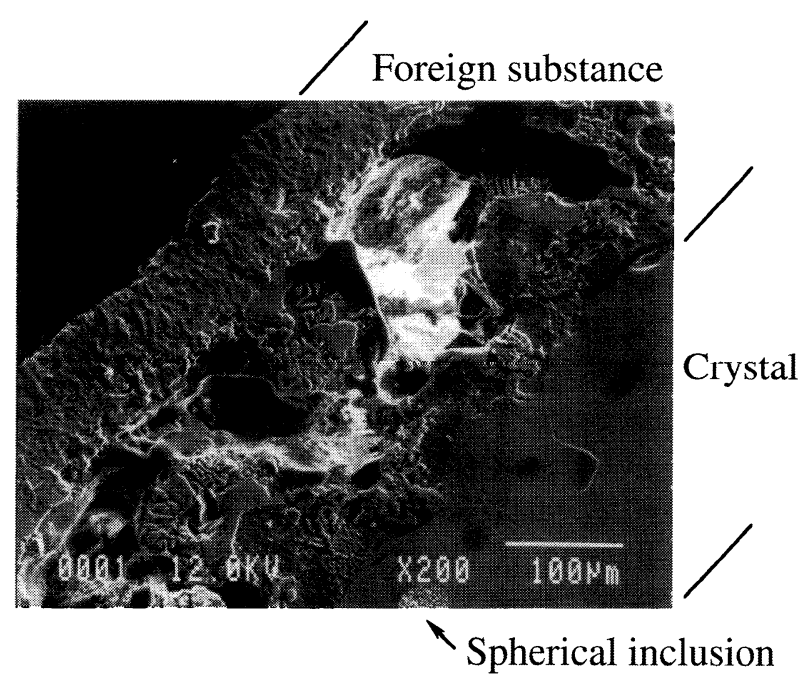

Fig.2 A SEM image of a cross-section of the as-grown crystal with foreign substances on the crystal surface. 


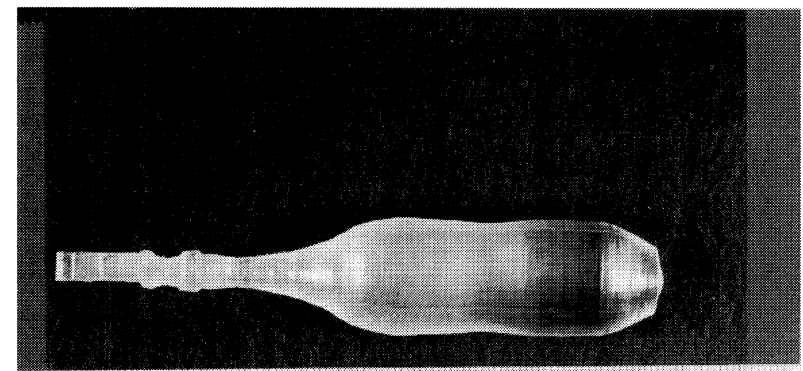

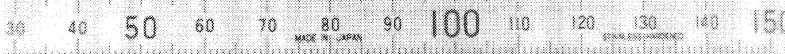

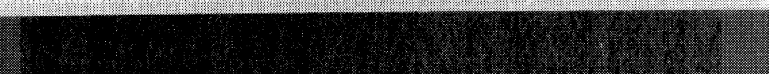

Fig.3 Crack and inclusion free as-grown $\mathrm{LiCaAlF}_{6}$ single crystal doped with $\mathrm{Ce}$ and $\mathrm{Na}$.

りに高純度 $\mathrm{CF}_{4}$ ガス $(6 \mathrm{~N})$ を用いることとした．融液組成に は, 蒸発成分を考慮する意味で, $\mathrm{AlF}_{3}, \mathrm{LiF}$ それぞれ化学 量論組成に対し $1 \mathrm{~mol} . \%$-richの条件とした，以上の条件で 作製した結晶をFig.3に示す．白濁物質の付着, クラック,イ ンクルージョン等のない直径約 $18 \mathrm{~mm}$, 長さ約 $80 \mathrm{~mm}$ の $\mathrm{Ce}, \mathrm{Na}: \mathrm{LiCAF}$ 単結晶の作製に成功した。同様の条件で, Ce,Na:LiSAF単結晶を作製した結果, Fig.4に示す単結晶が 得られた。

次に直径1インチサイズの結晶成長を試みた。1インチ

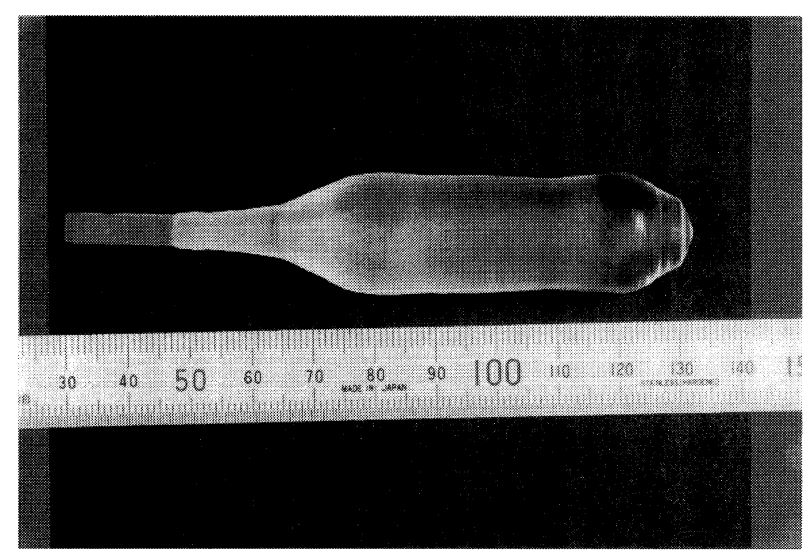

Fig.4 Crack and inclusion free as-grown $\mathrm{LiSrAlF}_{6}$ single crystal doped with $\mathrm{Ce}$ and $\mathrm{Na}$.

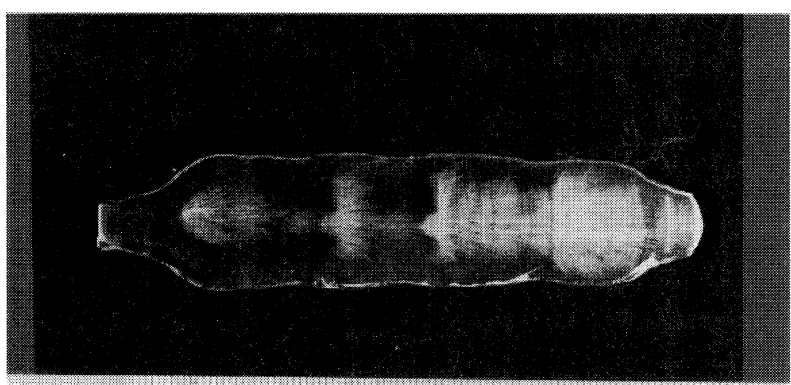

$\begin{array}{lllllllllllll}40 & 50 & 60 & 70 & 80 & 90 & 100 & 110 & 120 & 130 & 140 & 15\end{array}$

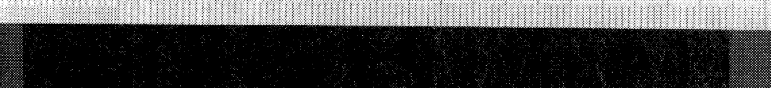

Fig.5 Ce,Na:LiCaAlF 6 wafer cut parallel to the growth axis of the crystal with inclusions.
サイズの単結晶化にあたり, 次の二つの点が問題となっ た。一つはインクルージョンの発生である. Fig.5にイン クルージョンの発生した結晶の成長軸方向に平行に切断, 研磨したウェハーを示す。引き上げ速度, 結晶回転数など の成長パラメーターを一定にした条件において直径 $18 \mathrm{~mm}$ の時と比較すると, インクルージョンの発生が容易になる 傾向が見られた。特に肩部での結晶径の増加が緩やかで ない場合, 或いは直胴部において結晶径が一定に保たれな い場合, 容易にインクルージョンが発生している様子がわ かる. 従って, インクルージョンの発生の抑制には, 急激 な直径変動をできるだけ抑制する必要があるとわかっ た.二つ目の問題は, 結晶化率が増加し70\%程度になると, 融液組成の変化に起因する不純物相が発生してくること である。Fig.6に結晶底部に不純物相が発生した結晶写真 を示すが, 不純物相が発生すると, 冷却時に結晶全体に底 部よりクラックが発生してくることがわかる. そこでこ のような不純物相の発生, これに伴うクラックの発生の抑 制のためには融液組成の最適化が必要であるが,ここでは 結晶化率が60\%程度に達した時点で結晶成長を終了するこ とでこの問題を回避することとした．Fig.7に作製した1イ ンチサイズCe,Na:LiCAF単結晶を示す。結晶径の変動を抑 え, 適当な結晶化率で結晶成長を終了することで, クラッ

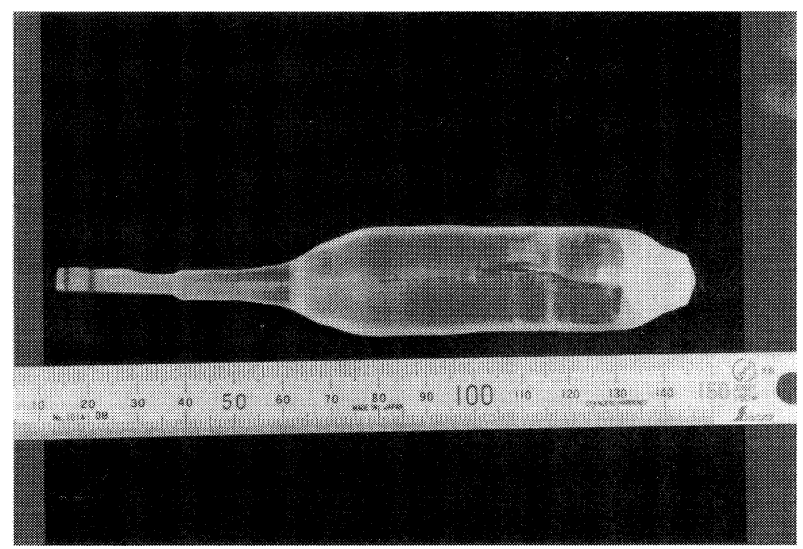

Fig.6 As-grown Ce,Na:LiCaAlF 6 crystal with impurity phase at the bottom of the crystal, and large crack parallel to the growth axis. Solidification fraction is $70 \%$.

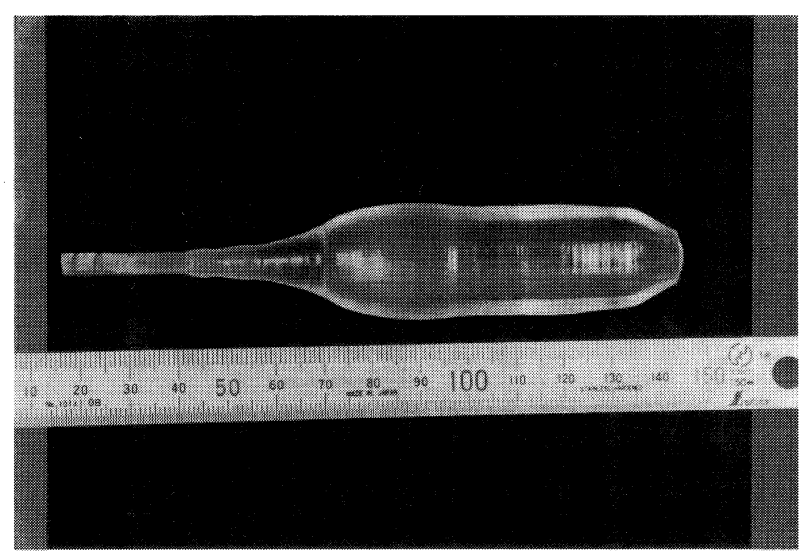

Fig.7 1-inch size as-grown $\mathrm{Ce}, \mathrm{Na}: \mathrm{LiCaAlF}_{6}$ single crystal free from cracks and inclusions. 


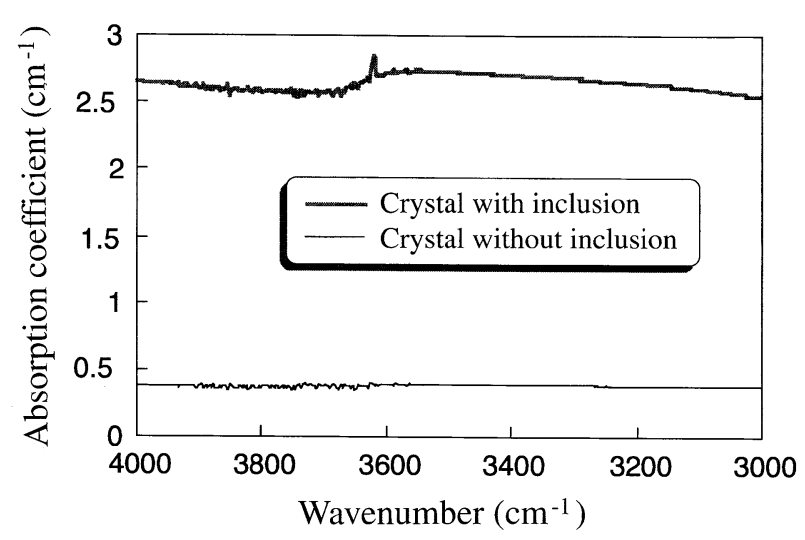

Fig. 8 Absorption spectra of Ce, $\mathrm{Na}: \mathrm{LiCaAlF}_{6}$ single crystal in IR wavelength region.

ク,インクルージョン等のない, 透明単結晶が得られた。 なお, 可視光レーザーなどを成長結晶に照射してみた結果, スキャッタリングセンターなどの存在は一切観察されな かった. Ce,Na:LiCAF, Ce,Na:LiSAFに扮けるCeの実効偏析 係数はそれぞれ0.021,0.013と求まり, CeはLiCAFの方によ り入りやすい傾向が見られた。

\section{2 光学特性評価}

フッ化物単結晶内における $\mathrm{OH}$ 一基の存在は高品質化を 妨げるのみでなく, レーザー特性の劣化をももたらす8,9). そこで作製結晶に対し赤外スペクトルを測定した。結晶 内に $\mathrm{OH}$ - 基が存在する場合, $3620 \mathrm{~cm}^{-1}$ 近辺に吸収ピーク が観察されるためである. Fig.8にFig.5の結晶に対し赤外 スペクトルを測定した結果を示す．インクルージョン部 分においては $3620 \mathrm{~cm}^{-1}$ 近辺に明瞭な吸収ピークが観察さ れ, $\mathrm{OH}$ - 基に起因する物質が混入していることがわかる が, インクルージョンのない部分においては特別な吸収 ピークが観察されず, 異物質などが存在しないことがわか る.インクルージョンを含まない他の結晶についても同 様に吸収ピークが観察されなかったことから, 今回作製し た結晶は $\mathrm{OH}$ 一基に起因する異物質をほとんど含まない高 品質結晶であると分かった。

Ce,Na:LiCAFとCe,Na:LiSAFに対し, 紫外から可視領域に おける吸収スペクトルを測定した結果, 両結晶とも $\mathrm{Nd}$ : YAGレーザーの第4高調波 $(4 \omega, 266 \mathrm{~nm})$ で直接励起可能で あることを示すピークが観察された。そこでレーザー発

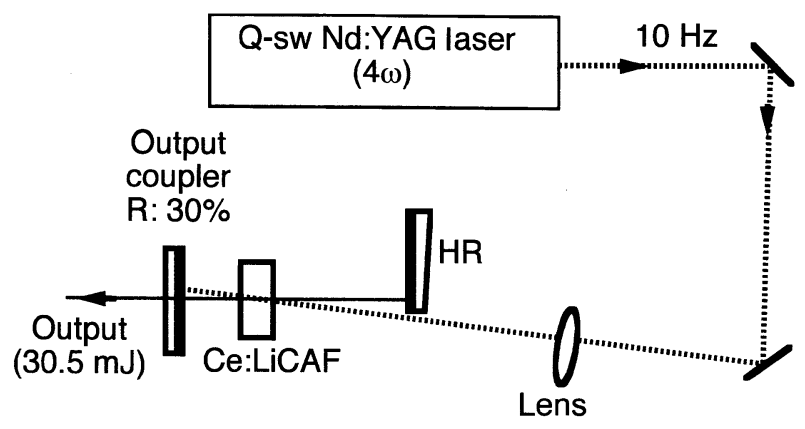

Fig.9 Experimental setup of the $\mathrm{Ce}, \mathrm{Na}: \mathrm{LiCaAlF}_{6}$ laser oscillator pumped by the fourth harmonic of a Qswitched Nd:YAG laser.

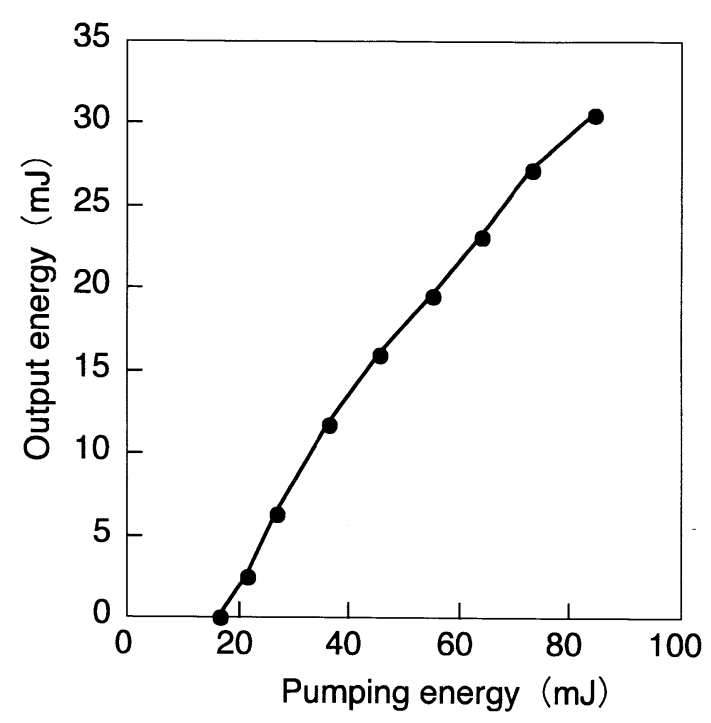

Fig.10 Laser output energy as a function of absorbed pump energy in a $\mathrm{Ce}, \mathrm{Na}: \mathrm{LiCaAlF}_{6}$ sample.

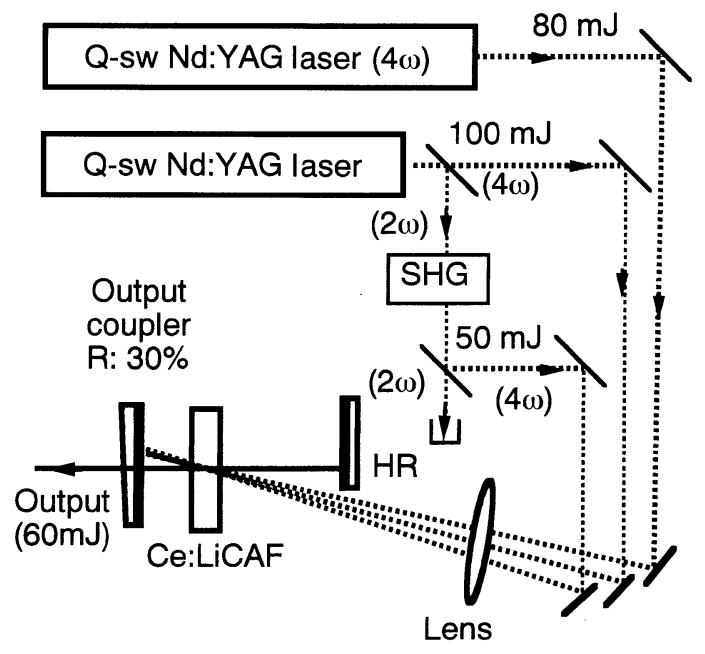

Fig.11 Experimental setup of a high-energy $\mathrm{Ce}$, $\mathrm{Na}: \mathrm{LiCaAlF}_{6}$ laser.

振実験を試みた。Fig.9に共振器の模式図を示す。レー ザー共振器は, 290nmに対して $30 \%$ の反射率と $266 \mathrm{~nm}$ に対し て75\%の透過率を持つ出力ミラーと高反射率平板ミラーを $4 \mathrm{~cm}$ の間隔でおくことで構成した. 長さ $10 \mathrm{~mm}$, 共振器の光 学軸に対し垂直な両端面がコーティングされていない Ce,Na:LiCAF結晶を共振器の中に置いた。励起源としては

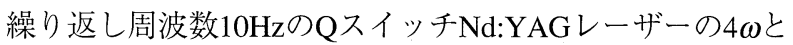
した. Fig.10に発振波長289nmにおけるレーザーの入出力 特性を示す. スロープ効率 $39 \%$, 最高出力 $30.5 \mathrm{~mJ}$ が得られ, これは著者の知りうる範囲では世界最高出力となる ${ }^{10,11)}$. 次により大出力を得るため, 入力エネルギーの大出力化が 可能となる配置を考えた. Fig.11に共振器構造の模式図を 示す. 2種類のQスイッチ $\mathrm{Nd}: \mathrm{YAG}$ スーザーを用い, 総入力 エネルギーが $230 \mathrm{~mJ}$ とるような設計とした。このような 条件下, 最大出力で $60 \mathrm{~mJ}$ のパルスエネルギーを, 今回作製 したCe,Na:LiCAF単結晶から得ることに成功した.今後は より大出力化, 紫外域での超短パルスレーザーの実現を検 討していきたい. 


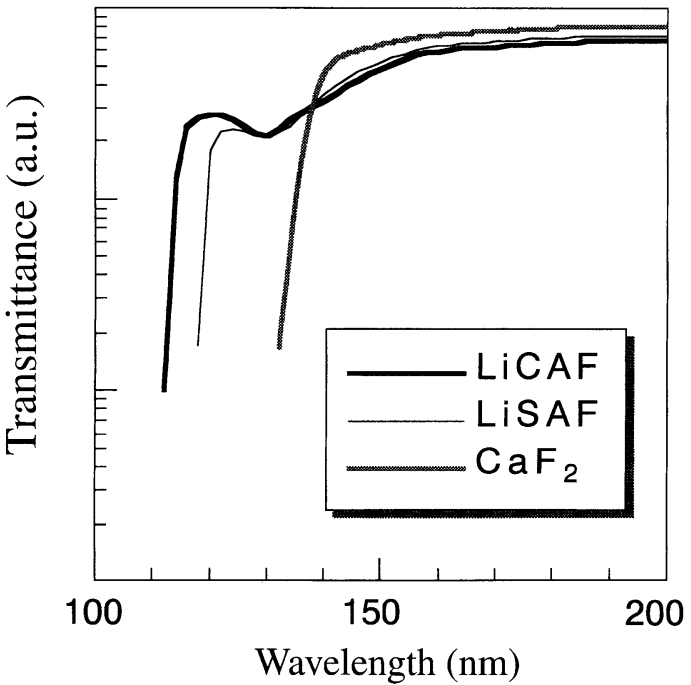

Fig.12 Absorption spectra of $\mathrm{LiCaAlF}_{6}$ and $\mathrm{LiSrAlF}_{6}$ single crystals in UV wavelength region, compared with that of $\mathrm{CaF}_{2}$ single crystal.

Colquiriite型LiCAF, LiSAF単結晶においては, 前述したよ うにCrドープ結晶に関する報告は多いがCe添加結晶, 並び に無添扣結唱の報告はほとんどない。とのため, 無添加結 晶における光学的基礎物性である吸収端の報告もない. 今回, Ceドープ結晶と同じ条件にて無添加LiCAF, LiSAF結 晶が得られたので, 無添加LiCAF, LiSAFに関して真空紫外 域での吸収スペクトルを測定することで吸収端の測定を 試みた. Fig.12に真空紫外域での吸収スペクトル測定結果 を示す。LiCAF, LiSAFは従来紫外域での空材として期待 される $\mathrm{CaF}_{2}$ よりも短い吸収端を示した。特にLiCAFが最も 短い吸収端, 112nmを示した。このことから, Colquiriite型 結晶, 特にLiCAFは新しい空材としても大きな期待が持て ることがわかった。

\section{Scheelite型結晶}

$\mathrm{LiYF}_{4}(\mathrm{YLF})$ に代表されるScheelite型結晶は, 正方晶系に 属するレーザー用結晶として古くから検討されている12). 紫外レーザー用材料としての検討は, 1980年頃にMoultonら により報告されたエキシマレーザー励起のCe:YLFが最初 である。近年, Ce:YLFに比ベソラリゼーションが軽減され たCe:LiLuF Le:LLF $_{4}$ がDubinskiiらにより開発された13).

Scheelite型フッ化物単結晶はColquiriite型結晶と同様, 紫外 波長可変固体レーザーとして期待されるが,特にLLFなど, HFガスなどの危険なガスを使用しない条件下での結晶成 長についてはほとんど報告されておらず,また現在におい ても結晶材料自体の入手が困難な状況となっている。そ こで, Colquiriite型結晶で得られた条件を踏まえ, YLF, LLF のバルク単結晶成長を試みたので報告する。

\section{1 単結晶成長}

単結晶作製には抵抗加熱型 $\mathrm{Cz}$ 炉を用い, 高純度 $\mathrm{Ar}(6 \mathrm{~N})$, 及び $\mathrm{CF}_{4}(6 \mathrm{~N})$ の二種を雲囲気ガスとして比較検討した. 白 金製の坩堝を用い, 出発原料には高純度 (99.99\%以上)の
$\mathrm{LiF}, \mathrm{YF}_{3}, \mathrm{LuF}_{3}, \mathrm{CeF}_{3}$ 各フッ化物粉末を使用した。引き上げ 速度, 結晶回転数はそれぞれ $1 \mathrm{~mm} / \mathrm{h}, 15 \mathrm{rpm}$ に固定し, $a$ 軸に 配向した種結晶を用い, $a$ 軸方向での結晶成長を行った。相 同定はXRD, $\mathrm{OH}$-基の存在の有無はFT-IRにより調べた.

YLFは調和溶融組成をもたないため, LiF-richの組成で出 発原料を準備する必要がある14)。そこで, モル比で $\mathrm{YF}_{3}$ : $\mathrm{LiF}=0.49: 0.51$ となるように原料を秤量した。結晶成長 に先立ち, 炉内を $10^{-2}$ torr程度の真空にし, その後高純度 $\mathrm{Ar}$ ガス雲囲気下で原料を融解したところ, 融液表面に多量の 異物質が発生した。このような条件で結晶成長を行った ところ, 結晶全域に渡り白濁し, 透明な部分の全く見られ ない結晶が得られた。そこでXRDにより, 構成物質の相同 定を行った結果, 主にYLF相からなっているが, かなりYOF $(\mathrm{CeOF})$ 相が混入していることがわかった。また, 融液表 面に浮遊していた物質も調べた結果, 同様の物質で構成さ れていることがわかった。

異物質である REOF $(\mathrm{RE}=\mathrm{Y}, \mathrm{Ce})$ 相の生成原因として, 原料である $\mathrm{REF}_{3}$ が炉内, あるいは原料中に含まれる微量の 水分と反応したことが考えられる15).

$$
\mathrm{REF}_{3}+\mathrm{H}_{2} \mathrm{O} \longrightarrow \mathrm{REOF}+2 \mathrm{HF}
$$

希土類フッ化物は水分と反応し, 容易に酸化フッ化物を 形成する。そこで, 雲囲気に $\mathrm{CF}_{4}$ ガスを用いることで, 以下 の反応によりREOFの生成を防ぐことを試みた。

$$
\mathrm{CF}_{4}+2 \mathrm{H}_{2} \mathrm{O} \longrightarrow \mathrm{CO}_{2}+4 \mathrm{HF}
$$

また, 原料融解前により高い真空度が達成できるように し, 炉内, 原料内に存在する水分除去の効率化を図った。 $\mathrm{LiF}$ の蒸発が見られたが, 融液組成がYF- $\mathrm{F}_{3}$-rich側に変動する と結晶作製が困難となるので, $\mathrm{LiF}$ 少し多くした組成 $\mathrm{YF}_{3}$ $: \mathrm{LiF}=0.48: 0.52$ で原料を調整した。このような条件下で, 結晶作製を試みた結果をFig.13に示す.クラック,インク ルージョン等のない直径 $18 \mathrm{~mm}$, 長さ $70 \mathrm{~mm}$ の高品質透明単 結晶が得られた。不純物相や異物質の発生が見られず, 高 品質結晶作製において $\mathrm{CF}_{4}$ ガスの適用が有効であることが わかった。同様の条件にて作製したCe:LLF結晶をFig.14に 示す. CeのYLF, LLFそれぞれの単結晶内における実効偏 析係数を調べたところ, 0.116, 0.054とそれぞれ求まった.

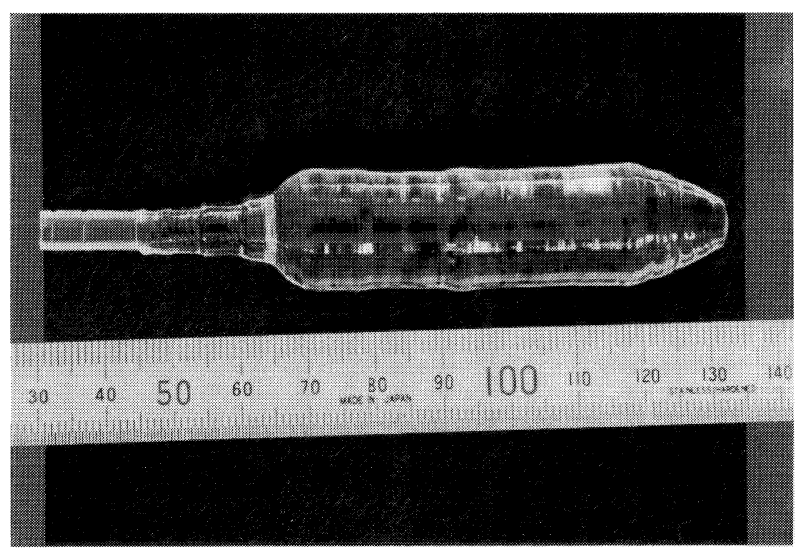

Fig.13 Crack and inclusion free as-grown $\mathrm{LiYF}_{4}$ single crystal doped with $\mathrm{Ce}$. 


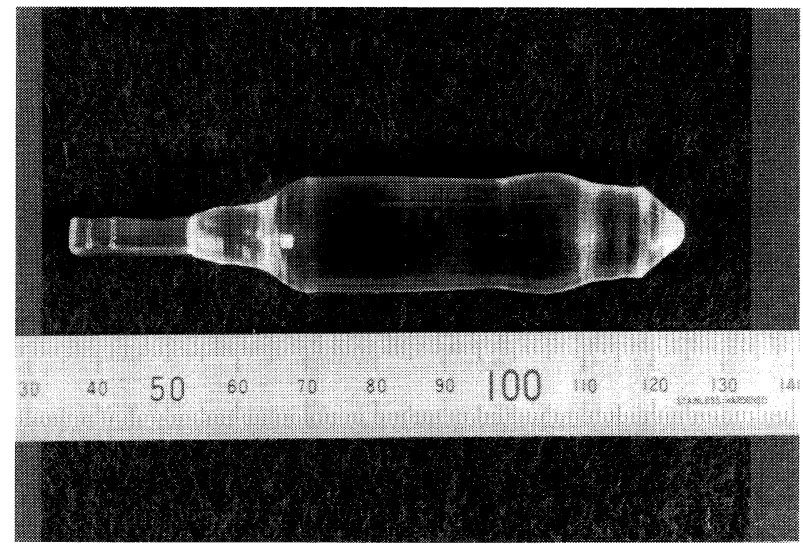

Fig.14 Crack and inclusion free as-grown $\mathrm{LiLuF}_{4}$ single crystal doped with $\mathrm{Ce}$.

実効偏析係数としては小さな值であるが, Colquiriite型結晶 と比較するとほぼ1ケ夕大きい值となっていた。

\section{2 光学特性評価}

作製結晶についてFT-IRによりレーザー特性を低下させ る原因となる $\mathrm{OH}$ 一基の存在を調べた結果をFig.15に示 す。作製した結晶においては, $3500 か ら 3600 \mathrm{~cm}^{-1}$ の範囲で 吸収が見られなかった。これに対し, 市販品であるLitton Airtron社製のNd:YLFでは4000 $\mathrm{cm}^{-1}$ 近辺を中心に幅広く,か つ強い吸収が見られた。これは金属と $\mathrm{OH}$ 一基の化合物に 起因するものと考えられる。この結果より, 今回我々が作 製したScheelite型フッ化物結晶は高い品質を持つことがわ かった。

紫外から可視領域における吸収スペクトルをCe:YLF, Ce:LLFに対し測定した．その結果, Nd:YAGレーザーの4 $4 \omega$ での直接励起は困難であるが, Nd:YAGレーザーの5 5 での 直接励起が可能であることがわかった．全固体紫外レー ザーとしての特性評価は現在進行中である.

\section{4. まとめ}

再現性良く高品質フッ化物単結晶を作製する手法を見 いだし, Ce,Na:LiCAF, Ce,Na:LiSAFの1インチサイズ単結晶, およびCe:YLF, Ce:LLFの単結晶成長に成功した。各結晶に おけるCeの実効偏析係数はかなり小さく, Ceは取り込まれ にくい元素であることがわかった．作製したCe,Na:LiCAF は289nmにおいて最大 $60 \mathrm{~mJ}$ という高出力のレーザーを発 振した。またLiCAFは112nmという短波長において吸収端

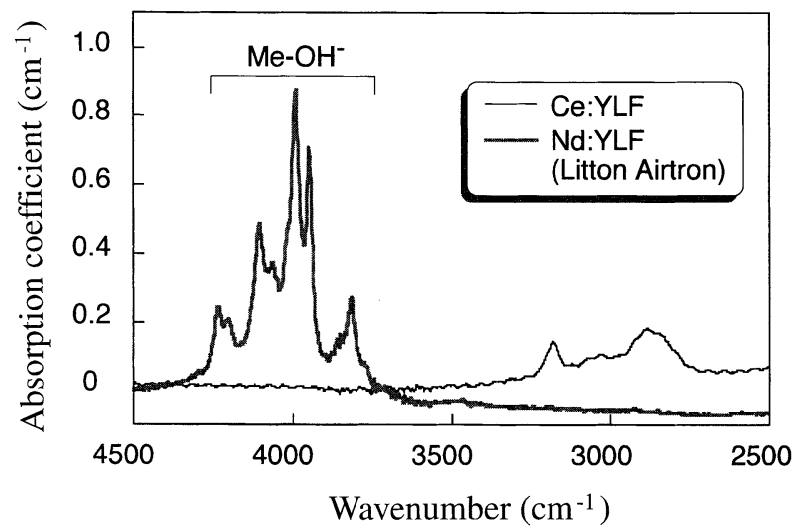

Fig.15 Absorption spectra of doped $\mathrm{LiYF}_{4}$ single crystal in IR wavelength region.

を示した。LiCAFは今後全固体紫外レーザー材料, 並びに 紫外域での空材として大きな期待を持てることがわかっ た. 今後は, 本研究にて得られた高品質フッ化物結晶成長 技術により,様々な新しいフッ化物単結晶材料を作製し, 新 しい光技術の発展に貢献したい.

\section{参考文献}

1) R. F. Belt and R. Uhrin: J. Cryst. Growth 109 (1991) 340.

2) S. A. Payne, L. L. Chase, H. W. Newkirk, L. K. Smith, and W. F. Krupke: IEEE J. Quantum Electron. 24 (1988) 2243.

3) S. A. Payne, L. L. Chase, L. K. Smith, W. L. Kway, and H. W. Newkirk: J. Appl. Phys. 66 (1989) 1051.

4) M. A. Dubinskii, V. V. Semashko, A. K. Naumov, R. Yu. Abdulsabirov, and S. L. Korableva: Laser Phys. 3 (1993) 216.

5) M. A. Dubinskii, V. V. Semashko, A. K. Naumov, R. Yu. Abdulsabirov, and S. L. Korableva: J. Mod. Opt. 40 (1993) 1.

6) V. K. Castillo and G. J. Quarles: J. Cryst. Growth 174 (1997) 337.

7) D. Klimm and P. Reiche: Cryst. Res. Technol. 33 (1998) 409.

8) I. M. Ranieri, S. L. Baldochi, A. M. E. Santo, L. Gomes, L. C. Courrol, L. V. G. Tarelho, W. de Rossi, J. R. Berretta, F. E. Costa, G. E. C. Nogueira, N. U. Wetter, D. M. Zezell, N. D. Vieira Jr., and S. P. Morato: J. Cryst. Growth 166 (1996) 423.

9) S. P. Morato, L. C. Courrol, L. Gomes, V. Kalinov, and A. Shadarevich: Phys. Stat. Sol. 163 (1991) K61.

10) Z. Liu, S. Izumida, H. Ohtake, N. Sarukura, K. Shimamura, Na Mujilatu, S. L. Baldochi, and T. Fukuda: Jpn. J. Appl. Phys. 37 (1998) L1318.

11) K. Shimamura, Na Mujilatu, K. Nakano, S. L. Baldochi, Z. Liu, H. Ohtake, N. Sarukura, and T. Fukuda: J. Cryst. Growth 197 (1999) 896.

12) R. E. Thoma, C. F. Weaver, H. A. Friedman, H. Insley, L. A. Harris, and H. A. Yakel, Jr.: J. Phys. Chem. 65 (1961) 1096.

13) M. A. Dubinskii: Laser Phys. 3 (1993) 216.

14) P. Rogin and J. Huliger: J. Cryst. Growth 179 (1997) 551.

15) R. Uhrin, R. F. Bert, and V. Rosati: J. Cryst. Growth 38 (1977) 38.
紫外レーザー用フッ化物単結晶

(fluoride single crystals for UV laser)

潜在的波長可変領域が紫外域の 275-340nm である $\mathrm{Ce}^{3+}$ イオンをドープしたフッ化物単結晶. 1980年ごろに報告 された $\mathrm{Ce}^{3+}: \mathrm{YLiF}_{4}(305-335 \mathrm{~nm}), \mathrm{Ce}^{3+}: \mathrm{LaF}_{3}(275-315 \mathrm{~nm})$ をは じめとし, 近年ではC $\mathrm{Ce}^{3+}: \mathrm{LuLiF}_{4}(305-340 \mathrm{~nm}), \mathrm{Ce}^{3+}: \mathrm{LiCaAlF}_{6}$ (280-320nm), Ce ${ }^{3+}: \operatorname{LiSrAlF}_{6}(280-320 \mathrm{~nm})$ などが報告されて
いる。これらは $\mathrm{KrF}$ エキシマレーザー $(248 \mathrm{~nm})$ や $\mathrm{Nd}: \mathrm{YAG}$ レーザーの第4高調波 $(266 \mathrm{~nm})$, 第5高調波 $(213 \mathrm{~nm})$ などで励 起可能である.こうした結晶の開発により, 全固体紫外波 長可変レーザーへの道が開けつつある. 全固体紫外波長 可変レーザーの広い利得帯域は, 超短パルス光の増幅・発 生などへの応用が期待されている.

(島村 清史) 